\title{
Predictors of end stage lung disease in systemic sclerosis
}

\section{Steen}

\section{Recognition of the two types of lung disease is important because their predictors and treatment differ}

$\mathrm{P}$ ulmonary disease is now the leading cause of death in patients with scleroderma. Of the 2000 patients in the Pittsburgh scleroderma databank, 211 patients have died of lung disease over the past 20 years. One hundred and thirteen died from isolated pulmonary hypertension and 98 died of pulmonary interstitial fibrosis. These account for $21.5 \%$ of the 981 deaths and $44 \%$ of the scleroderma related deaths. Recently, progress has been made in the treatment of specific lung problems in scleroderma so it is imperative that we have a better understanding of the predictors of these complications. Most important is the acknowledgement and recognition that there are two types of lung disease in scleroderma which are very different in their pathogenesis, clinical associations, predictive factors, and treatment. The investigators of "Predictors of end stage lung disease in a cohort of patients with scleroderma" in this issue of the Annals admit that a limitation of their study was that they were unable to separate their patients into the two types of lung disease. ${ }^{1}$ By combining these two types of lung disease they were unable to identify factors that would have likely been predictors of one of the forms of lung disease. It is extremely important to look carefully at the two types of lung disease individually and not lump them all together as end stage lung disease.

\section{PULMONARY INTERSTITIAL FIBROSIS}

Pulmonary interstitial fibrosis is felt to result from an alveolitis, which leads to interstitial fibrosis. ${ }^{2}$ In some patients there may be a significant vascular component, as there is in other manifestations of the disease. However, the interactions of these two components is incompletely understood and thus, we will focus primarily on the inflammation and fibrosis component. In interstitial lung disease, treatment with cyclophosphamide may be helpful for the inflammatory aspects of the disease, which occur before the development of severe fibrosis, though this is still experimental. High resolution computed tomography and bronchoalveolar lavage are the primary tools used to determine the extent of continuing inflammation in patients with scleroderma, but before performing these tests we must identify patients who are at high risk of having inflammation.

\section{Forced vital capacity}

A study of patients with severe interstitial fibrosis showed that although symptoms of lung disease did not develop early in the course, the loss of volume on pulmonary function testing was greatest in the first four years of disease. ${ }^{4}$ This is consistent with Morgan's study, which confirmed that the presence of an abnormal forced vital capacity (FVC) early in the disease is one of the most important risk factors for end stage lung disease. In another study, we found that $62 \%$ of the patients who ever reached an FVC of $<55 \%$ of the predicted value did so in the first five years after the onset of their very first symptom related to scleroderma.

\section{"An early abnormal FVC is an important risk factor for end stage interstitial lung disease"}

Patients with more than five years of disease who previously have had normal or only mildly abnormal FVCs are much less likely to develop severe fibrotic disease later in the course of their disease. They may have significant restrictive disease that developed early in their illness, but several studies have shown that unlike idiopathic pulmonary fibrosis, progression of disease in scleroderma does not always occur. ${ }^{6}$ Many patients have mild to moderate disease which stabilises. These patients may have a further slow decline in FVC but it appears that early disease is the time at which patients are at greatest risk for inflammation and subsequent progressive interstitial fibrotic disease.

Thus, in the first five years of disease patients should have pulmonary function tests (PFTs) monitored closely, every six months, until lung function stabilises. Patients with very early disease who already have a decreased FVC and the patient with a documented decreasing FVC are those who should be identified for further study even if they are asymptomatic. In our series of patients with severe lung disease, although patients died after 10 years of disease, most of these patients did not develop any pulmonary symptoms until after they had significantly decreased FVCs. ${ }^{4}$

\section{Diffusing capacity}

The diffusing capacity usually parallels the decrease in the vital capacity and it is not the initial or the most sensitive test to use to identify patients at increased risk for fibrosis. ${ }^{7}$ The vascular component in scleroderma interferes with the diffusing capacity, preventing it from being a good marker in isolation from the vital capacity. We will see later that it is the diffusing capacity that is the most important measure in identifying patients at risk for the vasculopathy causing pulmonary hypertension.

\section{Antitopoisomerase antibody}

Antitopoisomerase antibody has consistently been associated with interstitial fibrosis, although it does not predict severe fibrosis. ${ }^{4}$ Some patients with the antibody have only mild fibrosis and other patients without the antibody have severe fibrosis. However, the antibody does identify patients at increased risk for some fibrosis. Anticentromere antibody has consistently been negatively associated with severe interstitial fibrosis. ${ }^{8}$ These patients almost never have severe fibrosis. However, patients with limited scleroderma with antitopoisomerase are at increased risk of severe fibrosis. In interstitial lung disease it appears that the antibody markers are stronger predictors than the scleroderma subsets of limited and diffuse scleroderma. Several studies have not shown a strong association between the severity of fibrosis and the extent and severity of skin thickening. ${ }^{9}{ }^{10}$ This is partly because there are patients with limited scleroderma (often with antitopoisomerase antibody) with fibrosis but also patients with diffuse scleroderma and anti-RNA polymerase III who have the most severe skin thickening, but they have a decreased incidence of severe lung disease. ${ }^{11}$ The nucleolar autoantibodies, anti-U3 RNP antibody and anti TH/To, are also associated with an increased risk of pulmonary disease. ${ }^{12}$ The strong association of anti-U3 RNP and antitopoisomerase with the African-American race clearly makes these patients with scleroderma at significantly increased risk for severe interstitial fibrosis. ${ }^{13}$ The associations of these antibodies with specific types of lung abnormalities are strong evidence that they reflect something in the pathogenesis of the overall disease that differentiates patients into one or another type of disease pattern.

\section{Other factors}

Other features such as sedimentation rate and proteinuria (as found in this 
Table 1 Algorithm for lung disease in systemic sclerosis

\begin{tabular}{|c|c|c|c|c|}
\hline \multirow[b]{2}{*}{ Clinical findings } & \multicolumn{4}{|l|}{ Type of lung disease } \\
\hline & Vasculopathy, isolated PHT & Alveolitis, interstitial PF & $\begin{array}{l}\text { Severe end stage } \\
\mathrm{PF}+/-, 2 \text { nd } \mathrm{PHT}\end{array}$ & $\begin{array}{l}\text { PF }+/ \text { - alveolitis, } \\
\text { excessive PHT }\end{array}$ \\
\hline $\begin{array}{l}\text { SSc subtype } \\
\text { Disease duration (years) }\end{array}$ & $\begin{array}{l}\text { Limited } \\
>10\end{array}$ & $\begin{array}{l}\text { Diffuse }>\text { limited } \\
<5\end{array}$ & $\begin{array}{l}\text { Diffuse }>\text { limited } \\
>5\end{array}$ & $\begin{array}{l}\text { Diffuse }>\text { limited } \\
>5\end{array}$ \\
\hline Autoantibody & $\begin{array}{l}\text { ACA, U3- RNP, Th/To (nucleolar } \\
\text { pattern) }\end{array}$ & $\begin{array}{l}\text { Scl70, Th/To } \\
\text { (nucleolar patterns) }\end{array}$ & $\begin{array}{l}\text { Scl70, Th/To } \\
\text { (nucleolar patterns) }\end{array}$ & $\begin{array}{l}\text { U3- RNP, Th/To, } \\
\text { (particularly nucleolar } \\
\text { patterns) }\end{array}$ \\
\hline \multirow[t]{3}{*}{ PFT results } & FVC $>75 \%$ & FVC $<75 \%$ & FVC $<50 \%$ & FVC $<70 \%$ \\
\hline & TLCO $<60 \%$ & $\mathrm{TLCO}<75 \%$ & $\mathrm{TLCO}<50 \%$ & $\mathrm{TLCO}<50 \%$ \\
\hline & $\mathrm{FVC} / \mathrm{TLCO}>1.6$ & $\mathrm{FVC} / \mathrm{TLCO}$ equal & FVC/TLCO equal & $\mathrm{FVC} / \mathrm{TLCO}>1.6$ \\
\hline $\mathrm{ECHO}, \mathrm{PA}$ systolic pressures $(\mathrm{mm} \mathrm{Hg})$ & $>30$ & Normal & $>30$ & $>50$ \\
\hline Other tests & $\begin{array}{l}\text { Right heart catherisation, } \mathrm{O}_{2} \\
\text { desaturation }\end{array}$ & $\mathrm{HRCT}, \mathrm{BAL}$ & $\mathrm{HRCT}, \mathrm{BAL}$ & $\begin{array}{l}\mathrm{HRCT}, \mathrm{BAL} \text {, right heart } \\
\text { catherisation }\end{array}$ \\
\hline Patient monitoring & TLCO, ECHO every 2 years & $\begin{array}{l}\text { PFTs, HRCT every } 6 \\
\text { months for } 2-3 \text { years }\end{array}$ & PFTs, ECHO yearly & PFTs, ECHO yearly \\
\hline Possible treatments & $\begin{array}{l}\text { Tracleer, Remodulin, Flolan, } \\
\text { oxygen, coumadin }\end{array}$ & CTX & $\begin{array}{l}\text { Possible CTX, oxygen, } \\
\text { coumadin }\end{array}$ & $\begin{array}{l}\text { Possible CTX, Possible } \\
\text { treatment for PHT, oxygen }\end{array}$ \\
\hline
\end{tabular}

paper) are too non-specific to be very helpful in identifying patients at increased risk specifically for interstitial lung disease. Oesophageal dysmotility has long been felt to have a potential role in the development of interstitial lung disease, ${ }^{14}$ but because it is almost universally present it also is not particularly helpful. Smoking has not been associated with increased incidence of pulmonary fibrosis, although there are questions as to whether it is more severe in smokers and whether the risk of malignancy is likely to be higher. ${ }^{15}$

\section{PULMONARY HYPERTENSION}

Isolated pulmonary hypertension is a vasculopathy of the pulmonary vessels which is characteristically seen in patients with longstanding limited scleroderma without significant interstitial fibrosis. There have been dramatic new developments in the treatment of pulmonary hypertension. Continuous infusions of prostacyclins, a novel recently approved treatment using an endothelin blocking agent (bosentan, Tracleer, is a well tolerated oral drug), and experimental use of sudinafil (Viagra) are revolutionising the treatment of this previously untreatable complication. $^{16}{ }^{17}$ It is thus extremely important that we know how to recognise, diagnose, and determine the risk factors for this form of the disease in comparison with interstitial fibrosis. Isolated pulmonary hypertension independent of pulmonary fibrosis was first reported in the early 1970s. Patients had longstanding limited scleroderma (or the previously used term CREST syndrome), usually with a minimum of 5-10 years of Raynaud's symptoms before the diagnosis of pulmonary hypertension. The mean duration of Raynaud's disease in our patients was 14 years. ${ }^{18}$

\section{Carbon monoxide transfer factor}

The carbon monoxide transfer factor (TLCO) is the best clue for predicting the development of isolated pulmonary hypertension. The vast majority of patients with scleroderma have a markedly decreased Tuco at the time of diagnosis of pulmonary hypertension. ${ }^{18}$

\section{"TLCO is the best predictor of pulmonary hypertension"}

Our recently completed case-control study of risk factors in 106 patients with pulmonary hypertension showed that the Tuco was a mean of $52 \%$ of the predicted value five years before the diagnosis of pulmonary hypertension (compared with $80 \%$ in patients without pulmonary hypertension). ${ }^{19}$ In a small subset of patients who had serial PFTs for 15 years before the diagnosis of pulmonary hypertension, there was a linear decrease of the TLCO from $80 \%$ of the predicted value at the time of the first PFT down to $40 \%$ of the predicted value at the time of diagnosis of pulmonary hypertension. Most of these patients had minimal to no interstitial disease and thus their FVCs were $>70 \%$ of the predicted normal value. In patients who have some fibrosis with a mildly decreased FVC, an FVC/TLCo ratio of 1.6-1.8 helps to identify an increased likelihood of having pulmonary hypertension.

\section{Echocardiograms}

Echocardiograms can be used to screen for pulmonary hypertension, although pulmonary artery pressures are often unreliable or cannot be determined for technical reasons. ${ }^{20}$ Also, a significant number of patients have a false positive or low level increase in pulmonary pressures. A right heart catheterisation is necessary to confirm the presence and degree of pulmonary hypertension. Additional studies are necessary to determine the significance and natural history of this "mild" type of pulmonary hypertension and, more importantly, whether early intervention with these newer agents can prevent or alleviate the development of the deadly form of pulmonary hypertension.

\section{Anticentromere antibody}

The anticentromere antibody is highly associated with limited scleroderma and it confirmed the impressions of an increased incidence of isolated pulmonary hypertension in limited scleroderma. However, patients with limited scleroderma without anticentromere antibody have similar risks of getting this type of pulmonary hypertension. ${ }^{8}$ Patients with typical diffuse scleroderma and/or antitopoisomerase are much less likely to get isolated pulmonary hypertension, although they do develop pulmonary hypertension secondary to severe interstitial fibrosis. There is a subset of patients, many of whom have a nucleolar antinuclear antibody pattern, either U3-RNP or anti-Th antibody, who develop a moderate amount of interstitial fibrosis early in their disease and then later get severe pulmonary hypertension which is out of proportion to the degree of severity of the fibrosis. The ratio of the FVC to Teco as described above can be helpful in differentiating the type of lung disease of these patients.

In summary, African-American patients with less than five years of diffuse scleroderma with a topoisomerase antibody and a decreased FVC are at the greatest risk for developing severe pulmonary fibrosis. In contrast patients with more than 10 years of limited scleroderma and an anticentromere antibody and a marked decrease in the Tuco are at greatest risk for getting isolated 
pulmonary hypertension. Table 1 lists the various associations and risk factors of the two forms of lung disease that an individual patient is most likely to have. This will guide doctors in evaluating and deciding whether there is an available treatment. However, all patients should have frequent PFTs and echocardiograms to determine the type and incidence of lung disease. With a better understanding of the different types of lung disease and the use of the more specific techniques such as high resolution computed tomography, bronchoalveolar lavage, and right heart catheterisation, we have the best chance of identifying patients with early alveolitis or pulmonary hypertension so that appropriate treatment can be given. Future treatment of these complications is likely to be directed specifically at the fibrosis of the interstitium or the pulmonary vessels or even both. Hopefully, newer drugs will make these lung complications as treatable as angiotensin converting enzyme inhibitors have been for renal crisis.

Ann Rheum Dis 2003;62:97-99

\section{Authors' affiliations}

V Steen, Georgetown University, Washington DC, USA

Correspondence to: Professor V Steen; steenv@georgetown.edu

\section{REFERENCES}

1 Morgan C, Knight C, Lunt M, Black CM,

Silman AJ. Predictors of end stage lung

disease in a cohort of patients with

scleroderma. Ann Rheum Dis

2003;62:146-50

2 White B, Moore WC, Wigley FM, Xiao HQ Wise RA. Cyclophosphamide is associated with pulmonary function and survival benefit in patients with scleroderma and alveolitis. Ann Intern Med 2000; 132:947-54.

3 Silver RM. Scleroderma. Clinical problems. The lungs. Rheum Dis Clin North Am 1996;22:825-40.

4 Steen VD, Conte C, Owens GR, Medsger TA $\mathrm{Jr}$. Severe restrictive lung disease in systemic sclerosis. Arthritis Rheum 1994;37:1283-9.

5 Steen VD, Medsger TA Jr. Severe organ involvement in systemic sclerosis with diffuse scleroderma. Arthritis Rheum 2000:43:2437-44.

6 Peters-Golden $M$, Wise RA, Schneider P, Hochberg M, Stevens MB, Wigley F. Clinical and demographic predictors of loss of pulmonary function in systemic sclerosis. Medicine (Baltimore) 1984;63:221-31.

7 Steen VD, Graham G, Conte C, Owens G, Medsger TA Jr. Isolated diffusing capacity reduction in systemic sclerosis. Arthritis Rheum 1992;35:765-70.

8 Steen VD, Powell DL, Medsger TA Jr. Clinical correlations and prognosis based on serum autoantibodies in patients with systemic sclerosis. Arthritis Rheum 1988;31:196-203.

9 Morelli S, Barbieri C, Sgreccia A, Ferrante L, Pittoni V, Conti F, et al. Relationship between cutaneous and pulmonary involvement in systemic sclerosis. J Rheumatol 1997;24:81-5.

10 Tashkin DP, Clements PJ, Wright RS, Gong H Jr, Simmons MS, Lachenbruch PA, et al. Interrelationships between pulmonary and extrapulmonary involvement in systemic sclerosis. A longitudinal analysis. Chest 1994;105:489-95.

11 Okano Y, Steen VD, Medsger TA Jr. Autoantibody reactive with RNA polymerase
III in systemic sclerosis. Ann Intern Med 1993; 1 19:1005-13.

12 Steen VD. Autoantibodies in systemic sclerosis. Bull Rheum Dis 1996:45:6-8.

13 Greidinger EL, Flaherty KT, White B, Rosen A, Wigley FM, Wise RA. African-American race and antibodies to topoisomerase I are associated with increased severity of scleroderma lung disease. Chest $1998 ; 114: 801-7$.

14 Kinuya K, Nakajima K, Kinuya S, Michigishi T, Tonami N, Takehara K. Esophageal hypomotility in systemic sclerosis: close relationship with pulmonary involvement. Ann Nucl Med 2001;15:97-101.

15 Steen VD, Owens GR, Fino GJ, Rodnan GP, Medsger TA Jr. Pulmonary involvement in systemic sclerosis (scleroderma). Arthritis Rheum 1985;28:759-67.

16 Badesch DB, Tapson VF, McGoon MD, Brundage $B H$, Rubin $L$, Wigley FM, et al. Continuous intravenous epoprostenol for pulmonary hypertension due to the scleroderma spectrum of disease. A randomized, controlled trial [see comments]. Ann Intern Med 2000; 132:425-34

17 Rubin LJ, Badesch DB, Barst RJ, Galie N, Black CM, Keogh A, et al. Bosentan therapy for pulmonary arterial hypertension. $N$ Engl J Med 2002;346:896-903.

18 Stupi AM, Steen VD, Owens GR, Barnes EL, Rodnan GP, Medsger TA Jr. Pulmonary hypertension in the CREST syndrome variant of systemic sclerosis. Arthritis Rheum 1986;29:515-24.

19 Steen VD, Medsger TA. Risk factors for the development of isolated pulmonary hypertension (PHT) in systemic sclerosis. Arthritis Rheum 1999;42(suppl 9):S189.

20 Macgregor AJ, Canavan R, Knight C, Denton $\mathrm{CP}$, Davar J, Coghlan J, et al. Pulmonary hypertension in systemic sclerosis: risk factors for progression and consequences for survival. Rheumatology (Oxford) 2001;40:453-9. 